\title{
CYP2D6*2 Allele
}

National Cancer Institute

\section{Source}

National Cancer Institute. CYP2D6*2 Allele. NCI Thesaurus. Code C46040.

Human CYP2D6*2 allele is located in the vicinity of 22q13.1 and is approximately $4 \mathrm{~kb}$ in length. This allele, a variant form of the CYP2D6 wild-type allele, encodes cytochrome P450 2D6*2 protein. The majority of haplotypes of the CYP2D6*2 allele exhibit SNPs (g.2850C > T; g.4180G>C) in exons 6 and 9 that result in R296C and S486T coding changes. These alterations in protein sequence have no significant effect on the enzymatic activity of the cytochrome P450 2D6*2 protein. 